\title{
Arus Puncak Ekspirasi Pada pasien PPOK
}

\author{
${ }^{1}$ Endrian Mulyady, ${ }^{2}$ Justitia Waluyo, $\&^{3}$ Revin Mardianti \\ 1, 2, 3 Prodi IImu Keperawatan STIKes Muhammadiyah Ciamis \\ endrian1987@gmail.com
}

\begin{abstract}
Abstrak
Penyakit Paru Obstruktif Kronik (PPOK) adalah penyakit kronis saluran napas yang ditandai dengan hambatan aliran udara khususnya udara ekspirasi dan bersifat progresif lambat. Arus Puncak Ekspirasi (APE) adalah metode sederhana, noninvasif, dan ekonomis untuk mengetahui kecepatan dan kekuatan dari ekspirasi, dengan satuan liter permenit. Tujuan dari penelitian ini adalah untuk mengetahui jenis kelamin, usia dan tinggi badan pada penderita PPOK di Rumah Sakit Umum Daerah Kabupaten Ciamis. Metode penelitian menggunakan deskriptif kuantitatif, populasi adalah penderita PPOK di Rumah Sakit Umum Daerah Kabupaten Ciamis. Teknik sampling yaitu accidental sampling diperoleh 30 orang. Hasil penelitian menunjukan bahwa arus puncak ekspirasi pada penderita PPOK semuanya pada kategori zona merah sebanyak 30 orang $(100 \%)$ dengan rincian jenis kelamin sebagian besar penderita PPOK adalah laki-laki yaitu sebanyak 17 orang $(56,7 \%)$, Usia sebagian besar penderita PPOK adalah usia 53-65 tahun sebanyak 12 orang $(40 \%)$, tinggi badan penderita PPOK berkategori $151-160 \mathrm{~cm}$ sebanyak 18 orang $(60 \%)$. Pasien yang terkena PPOK adalah penyakit progresif. Apakah jenis kelamin, usia dan tinggi badan tidak mempengaruhi Arus Puncak Ekspirasi (APE).
\end{abstract}

Kata Kunci: Jenis Kelamin, Umur, Tinggi Badan, APE, PPOK

\begin{abstract}
Chronic Obstructive Pulmonary Disease (COPD) is a chronic disease characterized by airway air flow resistance of the air especially expiration and is slowly progressive. Peak expiratory flow (PEF) is a simple method, noninvasive, and economical to know speed and strength of expiration, with units of liters per minute. The purpose of this study was to determine the sex, age and height in people with COPD at the General Hospital District Ciamis. The research method using quantitative descriptive, population is patient of COPD at General Hospital of Regency of Ciamis. Sampling technique is accidental sampling obtained 30 people. The results showed that the peak expiratory flows in people with COPD were all in the red zone category of 30 people $(100 \%)$ with the details of the sex most of COPD sufferers are male as many as 17 people $(56,7 \%)$, age of most people with COPD is the age of 53-65 years as many as 12 people $(40 \%)$, the height of patients with Chronic COPD categorized $151-160 \mathrm{~cm}$ as many as 18 people $(60 \%)$. Patients affected by COPD are progressive disease, whether sex, age and height do not affect Peak Expiratory Flow (PEF).
\end{abstract}

Keywords: gender, age, height, PEF, COPD

\section{PENDAHULUAN}

Penyakit Paru Obstruktif Kronik (PPOK) adalah penyakit kronis saluran napas yang ditandai dengan hambatan aliran udara khususnya udara ekspirasi dan bersifat progresif lambat (GOLD, 2011). Pengukuran Arus Puncak Ekspirasi (APE) adalah metode sederhana, noninvasif, dan ekonomis untuk mengetahui kecepatan dan kekuatan dari ekspirasi, dengan satuan liter permenit (Santosa, 2010).

PPOK di Daerah Kabupaten Ciamis belum terdapat angka yang jelas dikarenakan pendataan yang dilakukan dinas kesehatan di kelompokan terhadap penyakit pernafasan dengan jumlah 6.118 penderita termasuk penderita PPOK di 
dalamnya berdasarkan data tahun 2013. Berdasarkan data dari rekam medis Rumah Sakit Umum Daerah Ciamis penderita PPOK pada tahun 2014 sebanyak 575 orang pada tahun 2015 dari bulan Januari-Februari sebanyak 111 orang (RSUD Ciamis, 2015).

PPOK berdampak penurunan kekuatan kontraksi otot pernapasan sehingga menyebabkan kesulitan saat bernapas Fungsi paru-paru menentukan konsumsi oksigen seseorang, yakni jumlah oksigen yang diikat oleh darah dalam paruparu untuk digunakan tubuh. Arus Puncak Ekspirasi (APE) atau Peak Expiratory Flow (PEF) adalah ekspirasi paksa dari kapasitas total paru yang diukur dengan peak flow meter yang merupakan alat portable yang sederhana dan mudah diaplikasikan. Ini biasa digunakan untuk mendeteksi fungsi paru yang berhubungan dengan penyempitan saluran nafas. Pengukuran ini khususnya diperlukan bagi pasien yang tidak mampu mendeteksi obstruksi saluran pernafasan (Zapletal, 2013).

Berdasarkan hasil studi pendahuluan pada tanggal 10 Maret 2015 terhadap 5 pasien PPOK diperoleh hasil pengukuran arus puncak ekspirasi berada di zona merah $(<50 \%)$. Penelitian ini bertujuan untuk memperoleh gambaran jenis kelamin, umur, tinggi badan dan arus puncak ekspirasi pada penderita PPOK di Rumah Sakit Umum Daerah Kabupaten Ciamis.

\section{BAHAN DAN CARA}

Metode penelitian ini adalah deskriptif kuantitatif. Populasi dalam penelitian ini adalah penderita Penyakit Paru Obstruktif Kronik (PPOK) di Rumah Sakit Umum Daerah Kabupaten Ciamis sebanyak 111 orang pada bulan januarifebruari tahun 2015. Teknik pengambilan sampel yang digunakan dalam penelitian ini adalah accidental sampling. Accidental sampling pada penelitian ini menggambil siapa saja yang menderita Penyakit PPOK.

Proses penelitian dilaksanakan periode 04 sampai dengan 19 juni 2015. Sampel adalah pasien yang menjalani perawatan rawat di Rumah Sakit Umum Daerah Ciamis. Sampel dalam penelitian ini dalam kurun waktu tersebut adalah 30 orang penderita Penyakit Paru Obstruktif Kronik (PPOK). pengumpulan data arus puncak ekspirasi dilakukan melalui wawancara langsung kepada sampel penelitian dengan berpedoman pada instrumen penelitian, instrumen penelitian akan divalidasi terlebih dahulu. Data pengukuran tinggi badan, berat badan, jenis kelamin dan arus puncak ekspirasi yang akan didapat berupa data diskrit kontinu dengan cara mengulang 3 kali penggunaan Peak Flow Meter pada setiap penderita PPOK dan diambil nilai tertinggi dan dibandingkan dengan standar normal arus puncak ekspirasi. Penelitian ini telah dilaksanakan di Rumah Sakit Umum Daerah Kabupaten Ciamis pada tanggal 04-19 Juni 2015.

\section{HASIL PENELITIAN}

Hasil pengumpulan data mengenai APE pada pasien PPOK di RSUD Kabupaten Ciamis tahun 2015 diperoleh data sebagai berikut :

Tabel 1. Distribusi Jenis Kelamin Responden

\begin{tabular}{|c|c|c|c|}
\hline No & Jenis Kelamin & $\mathbf{F}$ & $\begin{array}{c}\text { Persentasi } \\
(\%) \\
\end{array}$ \\
\hline 1. & Laki-laki & 17 & 56,7 \\
\hline 2. & Perempuan & 13 & 43,3 \\
\hline & Jumlah & 30 & 100 \\
\hline
\end{tabular}

Berdasarkan tabel 1 diketahui bahwa jenis kelamin pada penderita Penyakit Paru Obstruktif Kronik (PPOK) Di Rumah Sakit Umum Daerah Kabupaten Ciamis, frekuensi tertinggi yaitu berkategori laki-laki sebanyak 17 orang $(56,7 \%)$ dan frekuensi 
terendah yaitu kategori perempuan sebanyak 13 orang $(43,3 \%)$.

Tabel 2. Distribusi Umur Pada Responden

\begin{tabular}{cccc}
\hline No & Usia & $\mathbf{F}$ & $\begin{array}{c}\text { Persentasi } \\
(\%)\end{array}$ \\
\hline 1. & 40-52 Tahun & 7 & 23,3 \\
2. & 53-65 Tahun & 12 & 40 \\
3. & 66-76 Tahun & 11 & 36,7 \\
\hline & Jumlah & 30 & 100 \\
\hline
\end{tabular}

Berdasarkan tabel 5 diketahui bahwa umur pada penderita Penyakit Paru Obstruktif Kronik (PPOK) Di Rumah Sakit Umum Daerah Kabupaten Ciamis, frekuensi tertinggi yaitu berkategori 53-65 tahun sebanyak 12 orang (40\%) dan frekuensi terendah yaitu kategori 40-52 tahun sebanyak 7 orang $(23,3 \%)$.

Tabel 3. Distribusi Tinggi Badan Pada Responden

\begin{tabular}{cccc}
\hline No & Tinggi Badan & F & $\begin{array}{c}\text { Persentasi } \\
(\%)\end{array}$ \\
\hline 1. & $130-140 \mathrm{Cm}$ & 1 & 3,3 \\
2. & $141-150 \mathrm{Cm}$ & 11 & 36,7 \\
3. & $151-160 \mathrm{Cm}$ & 18 & 60 \\
\hline & Jumlah & 30 & 100 \\
\hline
\end{tabular}

Berdasarkan tabel 3. diketahui bahwa tinggi badan pada penderita Penyakit Paru Obstruktif Kronik (PPOK) di Rumah Sakit Umum Daerah Kabupaten Ciamis, frekuensi tertinggi yaitu berkategori 151$160 \mathrm{~cm}$ sebanyak 18 orang $(60 \%)$ dan frekuensi terendah yaitu kategori 130-140 Cm sebanyak 1 orang (3,3\%).

Tabel 4. Distribusi Arus Puncak Ekspirasi Pada Responden

\begin{tabular}{cccc}
\hline No & $\begin{array}{c}\text { Arus Puncak } \\
\text { Ekspirasi }\end{array}$ & F & $\begin{array}{c}\text { Persentasi } \\
(\%)\end{array}$ \\
\hline 1. & Zona Hijau & 0 & 0
\end{tabular}

\begin{tabular}{|c|c|c|c|}
\hline & Zona Kuning & 0 & 0 \\
\hline & Zona Merah & 30 & 100 \\
\hline & Jumlah & 30 & 100 \\
\hline
\end{tabular}

Berdasarkan tabel 4. diketahui bahwa arus puncak ekspirasi pada penderita Penyakit Paru Obstruktif Kronik (PPOK) Di Rumah Sakit Umum Daerah Kabupaten Ciamis semuanya pada kategori zona merah sebanyak 30 orang $(100 \%)$.

\section{PEMBAHASAN}

Hasil penelitian menunjukan bahwa arus puncak ekspirasi pada penderita Penyakit Paru Obstruktif Kronik (PPOK) Di Rumah Sakit Umum Daerah Kabupaten Ciamis semuanya pada kategori zona merah sebanyak 30 orang (100\%). Hal ini menunjukan bahwa terjadi gangguan pada paru-paru penderita Penyakit Paru Obstruktif Kronik (PPOK) karena hasil data peak flow meter dapat menggambarkan tanda-tanda peringatan dini untuk suatu penyakit yang dalam beberapa kasus mungkin menunjukkan penurunan fungsi paru-paru, jenis kelamin tinggi badan dan usia merupakan hal yang dapat menunjukkan hasil perkiraan dari nilai peak flow.

Berdasarkan hasil analisis data karakteristik sebagian besar jenis kelamin penderita PPOK adalah laki-laki yaitu sebanyak 17 orang $(56,7 \%)$, hal ini mungkin disebabkan oleh faktor risiko seperti merokok dan bekerja di luar rumah yang mengakibatkan laki-laki lebih rentan terhadap penyakit PPOK.

Menurut Roserya (2011) tidak terdapat perbedaan yang mencolok sampai masa pubertas. Setelah masa pubertas, laki-laki memiliki nilai APE yang lebih tinggi. Hal ini disebabkan oleh beberapa hal, antara lain volume dan kapasitas paru laki-laki kira-kira 20-25\% diatas perempuan, perbedaan biologis, dan faktor sosial budaya dimana sesudah pubertas anak perempuan cenderung menghindari aktivitas fisik. 
Hal ini sesuai dengan penelitian Yunus (2010) dengan judul Kadar Desmosine Serum pada Penyakit Paru Obstruktif Kronik Stabil di RSUP Persahabatan yang mendapatkan laki-laki $(86,2 \%)$ lebih banyak dari perempuan $(13,6 \%)$. Wihastuti dkk (2001) tentang hubungan antara nilai faal paru dengan kualitas hidup penderita penyakit paru kronik mendapatkan laki-laki 95\% dan perempuan $5 \%$ pada penelitian tentang hubungan nilai faal paru dengan kualitas hidup penderita PPOK.

Hasil penelitian diadapatkan usia responden sebagian besar penderita PPOK adalah usia 53-65 tahun sebanyak 12 orang (40\%). Kejadian timbulnya PPOK biasanya dimulai pada umur $>40$ tahun dan dengan pertambahan umur maka keluhan semakin jelas. Disamping itu, pertambahan umur juga mengakibatkan penurunan faal paru.

Menurut Roserya (2011) usia berkolerasi secara curvilinear nilai fungsi paru, termasuk nilai arus puncak ekspirasi, meningkat seiring bertambahnya usia, dan akan mencapai nilai optimal sekitar usia 22 tahun, dan setelah itu akan mengalami penurunan seiring bertambahnya usia. Hal ini sesuai dengan penelitian Yunus (2010) dengan judul Kadar Desmosine Serum pada PPOK Stabil di RSUP Persahabatan yang mendapatkan umur terbanyak antara 61-80 tahun. Wihastuti (2001) tentang hubungan antara nilai faal paru dengan kualitas hidup penderita penyakit paru kronik mendapatkan rerata umur penderita PPOK adalah 65,4 tahun.

Hasil penelitian diadapatkan tinggi badan pada penderita PPOK di Rumah Sakit Umum Daerah Kabupaten Ciamis, frekuensi tertinggi yaitu berkategori 151$160 \mathrm{Cm}$ sebanyak 18 orang (60\%). Menurut Roserya (2011) semakin tinggi badan individu akan semakin tinggi pula nilai APE-nya. Jenis kelamin, umur, tinggi badan, berat badan, dan body surfacearea, merupakan faktor-faktor yang diduga dapat mempengaruhi Arus Puncak Ekspirasi (APE). Pada detik pertama mempengaruhi force expiratory volume dan forcevital capacity (Meenakshi et.al, 2012).

\section{KESIMPULAN}

Hasil penelitian menunjukkan bahwa pada pasien dengan PPOK terdistribusi paling banyak pada kategori laki-laki, usia 53 - 65 tahun, dengan tinggi badan 151$160 \mathrm{Cm}$, dan seluruh responden berada pada Arus Puncak Ekspirasi (APE) zona merah.

\section{SARAN}

Perlu penelitian lebih lanjut apakah karakteristik pasien dapat mempengaruhi Arus Puncak Ekspirasi.

\section{DAFTAR PUSTAKA}

GOLD, (2011). Global strategy for the diagnosis, management, and preventionof chronic obstructive pulmonary disease. Tersedia dalam : www.goldcopd.com [diakses 15 Maret 2015].

Meenakshi et.al, (2012). Antibacterial activity of simple ascidian ascidia sydneiensis (family: ascidiidae) against human pathogens. Journal of microbiology and biotechnology research

Rekam Medis RSUD Ciamis, 2015. Data PPOK.

Roserya (2011) Perbedaan antara nilai arus puncak ekspirasi sebelum dansesudah olahraga renang selama dua belas minggu. Program Pendidikan Sarjana Fakultas Kedokteran Universitas Diponegoro

PDPI, (2011). PPOK (Penyakit paru Obstruktif Kronik), pedoman praktis diagnosisdan penatalaksanaan di Indonesia. Perhimpunan Dokter Paru Indonesia (PDPI).

Santosa, (2010). Perbandingan nilai arus puncak ekspirasi antara perokok danbukan perokok. Jurnal kedokteran maranatha. Vol. 3 tersedia dalam 
http://majour.maranatha.edu diakses 15 maret 2015.

Zapletal, (2013). Forced expiratory parameter in healthy preschool children (3-6 years age). Pediatric Pulmonol. 